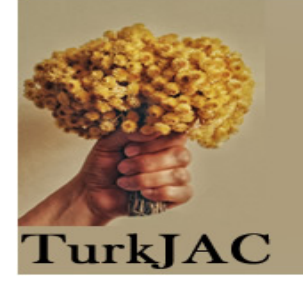

\title{
Solvent and molecular structure effects on acidity strength in non-aqueous medium
}

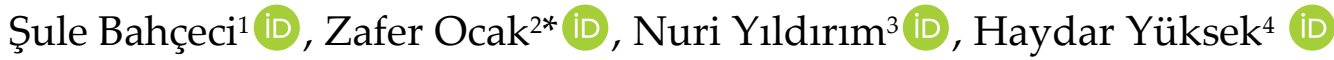 \\ ${ }^{1}$ Trabzon University, Fatih Education Faculty, Secondary Education Science and Mathematics Education, 61080, Trabzon, Turkey \\ ${ }^{2}$ Kafkas University, Education Faculty, Mathematics and Science Education,36100 Kars, Turkey \\ ${ }^{3}$ Karadeniz Technical University, Faculty of Science, Department of Chemistry, 61080, Trabzon, Turkey \\ ${ }^{4}$ Kafkas University, Faculty of Science \& Letters, Department of Chemistry, 36100 Kars, Turkey
}

\begin{abstract}
The acidic properties of ten 3-alkyl(aryl)-4-[3-hydroxy-4-methoxy benzylidenamino]-4,5-dihydro-1H-1,2,4-triazol-5-one derivatives were investigated. Amphiprotic solvents used in this study were isopropyl alcohol and tert-butanol. Acetone and N,N- dimethylformamide (DMF) were preferred as a dipolar aprotic solvent. Compounds were titrated with tetrabutylammonium hydroxide (TBAH) in isopropyl alcohol and titrimetric analyses were used potentiometric method determining the end-points, half-neutralization method determining acidity. Typical Sshaped titration graphs excepted were determined. The acidity strengths of 4,5-dihydro-1H-1,2,4-triazol-5-one derivatives in amphiprotic and dipolar aprotic solvents were calculated using tables and graphs. The $\mathrm{p} K_{\mathrm{a}}$ values obtained in the solvents were found to be differentiated. The effects of solvent, molecular structure, autoprotolysis constant dielectric constant, and leveling-differentiation effects of the solvents upon acidity strength of the compounds were discussed.
\end{abstract}

Keywords: Triazole, amphiprotic solvent, $\mathrm{p} K_{\mathrm{a}}$, potentiometry

\section{Introduction}

Potentiometry, one of the electrochemical methods, is widely used due to its wide advantages. Potentiometric techniques have long been used in landmark determination. It is simple and inexpensive in potentiometric methods [1]. Potentiometric titrations are one of the most widely used methods for determining acidity constants due to their simple and low cost. In the course of time, many different methods such as spectrometry, conductimetry, electrophoresis, NMR, polarimetry, calorimetry, theoretical, etc. were developed [2]. However, the potentiometric method does not include the restrictions specified in the determination of the equivalent point, so it is the most widely used method among these methods due to its simplicity, accuracy, and precision [3].

Thousands of potentiometric sensors have been successfully developed and applied in many fields such as medicine, environmental monitoring, agriculture, industry and pharmaceutical sciences $[4,5]$.

Among the electrochemical methods of the best techniques for antioxidant activity (AOA) assessment, potentiometry is where the potential shift of the platinum electrode, which is readily applicable and the source of information about AOA, is placed in a mediator system. Their advantages such as usability, speed, and easy measurement offer a direct evaluation of the electron-donor-acceptor properties of the system, ie the properties that determine the antioxidant status [68].

Using the dissociation constant, some thermodynamic parameters can be measured, such as enthalpy change $\left(\mathrm{H}^{\circ}\right)$, Gibb's energy change $\left(\Delta \mathrm{G}^{\circ}\right)$, and entropy change $\left(\Delta S^{\circ}\right)$. Enthalpy change of the decomposition process $\left(\Delta \mathrm{H}^{\circ}\right)$ Van't Hoff relation $\left(\mathrm{d} \operatorname{lnK} / \mathrm{dT}=\Delta \mathrm{H}^{\circ} / \mathrm{RT}^{2}\right)$ Gibb's free energy $\left(\Delta \mathrm{G}^{\circ}\right)$ is calculated using the equation $\Delta \mathrm{G}^{\circ}=2.303 \mathrm{RTpK}$. Using these calculated values of $\Delta \mathrm{H}^{\circ}$ and $\Delta \mathrm{G}^{\circ}$, the entropy change $\left(\Delta S^{\circ}\right)$ is determined by the equation $\Delta \mathrm{S}^{\circ}=\left(\Delta \mathrm{H}^{\circ}-\Delta \mathrm{G}^{\circ}\right) / \mathrm{T}[9]$.

In this article, some 3-alkyl(aryl)-4-(3-hydroxy-4methoxybenzylideneamino)-4,5-dihydro- $1 \mathrm{H}-1,2,4$ triazol-5-one derivates known to have biological
Citation: Ş. Bahçeci, Z. Ocak, N. Yıldırım, H. Yüksek, Solvent and
molecular structure effects on acidity strength in non-aqueous
medium, Turk J Anal Chem, 3(1), 2021, 27-32.

https://doi.org/10.51435/turkjac.939857
*Author of correspondence: zafcak@gmail.com

Tel: +90 (474) 2251262

Fax +90 (474) 2251264

Received: May 20, 2021

Accepted: June 02, 2021 
activities and acidic properties were used. The dissociation constants of the compounds were determined by the potentiometric titration method. [1015]. Acidic properties in solvents were investigated with respect to solvent effect, structure effect, dielectric constant, and autoprotolysis constants. The study will contribute to the literature in the field of acid-bases and buffer solutions.

\section{Materials and Methods}

\subsection{Reagents}

Ten 3-alkyl(aryl)-4-(3-hydroxy-4-methoxybenzylidenamino)-4,5-dihydro-1H-1,2,4-triazol-5-ones which acidity strengths have been determined are shown in Fig. 1. Compounds 1 has been synthesized according to the literature [16].

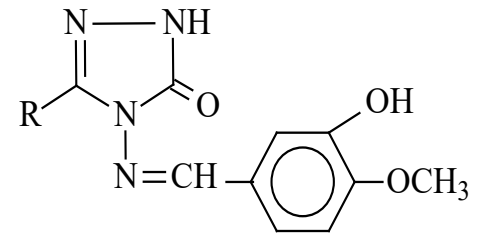

1

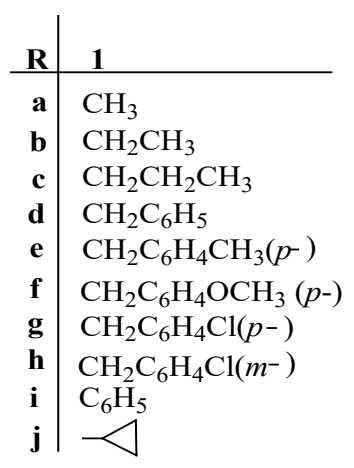

Figure 1. 3-Alkyl(Aryl)-4-(3-hydroxy-4-methoxybenzylidenamino)4,5-dihydro-1H-1,2,4-triazol-5-one compounds

\subsection{Solvents}

Isopropyl alcohol as an amphiprotic solvent for the determination of acidity constants of 3-alkyl(aryl)-4-(3hydroxy-4-methoxybenzylidenamino)-4,5-dihydro- $1 \mathrm{H}$ 1,2,4-triazol-5-ones, tert-butanol, DMF from dipolar aprotic solvents, and acetone were used. The wide potential range of solvents, the solubility of TBAH and 3-alkyl(aryl)-4-(3-hydroxy-4-methoxybenzylidenamino) -4,5-dihydro-1H-1,2,4-triazol-5-ones in the solvents, and the working possibility under room conditions were important factors in the selection of solvents. A solution of $0.05 \mathrm{~N}$ of TBAH in isopropyl alcohol was preferred as a titrant. Isopropyl alcohol, acetone DMF, and tertbutanol were purchased from Merck.

\subsection{Titrant}

As a titrant, TBAH has been a widely used base against acids. The standard $0.05 \mathrm{~N}$ concentration of TBAH in isopropyl alcohol was preferred.

\subsection{Apparatus}

In the study, measurements were made with a Jenway 3040-model ion analyzer. The sensitivity of the $\mathrm{pH}$ meter used in $\mathrm{pH}$ readings is \pm 0.002 , while the sensitivity in $\mathrm{mV}$ measurement is \pm 0.1 , and the precision is \pm 0.2 . A combined $\mathrm{pH}$ electrode was used in the studies. A $50 \mu \mathrm{L}$ micropipette was used for titrant addition.

\subsection{Solutions}

10-3 M solutions of 3-alkyl(aryl)-4-(3-hydroxy-4methoxybenzylidenamino)-4,5-dihydro-1H-1,2,4-triazol -5-ones in acetone, tert-butanol, isopropyl alcohol, DMF has also been prepared. A $0.05 \mathrm{~N}$ solution of TBAH in isopropyl alcohol was prepared as a titrant.

\subsection{Methods}

Two buffer solutions of $\mathrm{pH}=7,0$ and $\mathrm{pH}=10,0$ were used for calibration of the $\mathrm{pH}$ meter used. Potentiometric titrations were carried out at $25,0^{\circ} \mathrm{C}$. 3-Alkyl(Aryl)-4-(3hydroxy-4-methoxy benzyliden amino) -4,5-dihydro$1 \mathrm{H}-1,2,4$-triazol-5-ones in amphiprotic and dipolar aprotic solvents $10^{-3} \mathrm{M} 17,0 \mathrm{~mL}$ of its solution was taken. The acid solution was made homogeneous by mixing with a magnetic stirrer. With a micropipette, $0.05 \mathrm{~mL}$ of titrant each time was added to the stirring acid solution. $10^{-3} \mathrm{M}$ of acid derivatives of 3-alkyl(aryl)-4-(3-hydroxy4-methoxybenzylidenamino)-4,5-dihydro-1H-1,2,4triazol-5-one in amphiprotic and dipolar aprotic solvents. Its solution was titrated with $0.05 \mathrm{~N}$ TBAH and the results are expressed as a graph of $\mathrm{mV}-\mathrm{mL}$ TBAH.

\subsection{Determination of acidity constants with Half- neutralization method}

Titration graphs of mL TBAH-pH and mL TBAH-mV were drawn with the help of titration data. To determine the equivalent points, the graphs of TBAH - $\Delta \mathrm{E} / \Delta \mathrm{V}$ (first derivative) and mL TBAH - $\Delta^{2} \mathrm{E} / \Delta \mathrm{V}^{2}$ (second derivative) were used (Fig. 2). From these values, half-neutralization points were calculated [17-21].

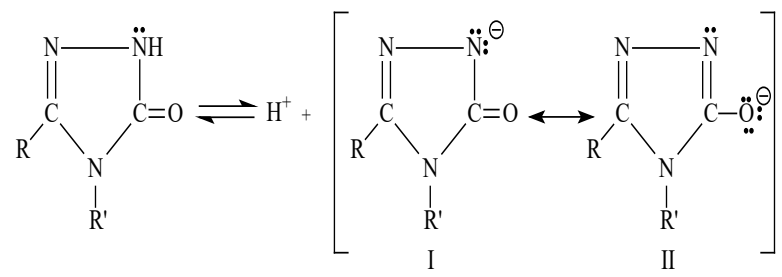

\section{Result and Discussion}

When the N-H hydrogen in the 4,5-dihydro- $1 \mathrm{H}-1,2,4-$ triazol-5-one ring is protonated, the equilibrium shifts to the right because the remaining electron pair is delocalized to include oxygen and is easy to accommodate.; hence the acidity increases (Equation 1). This is evidence that the N-H proton in the 4,5-dihydro$1 \mathrm{H}-1,2,4$-triazol-5-one ring system shows acidic properties. 
10-3 $\mathrm{M}$ of 3-alkyl(aryl)-4-(3-hydroxy-4methoxybenzylidenamino)-4,5-dihydro-1H-1,2,4-triazol -5-ones amphiprotic (isopropyl alcohol, tert-butyl alcohol) and dipolar aprotic, (DMF, acetone) as a titrant in solvent mediums, plotted from the data obtained by titration of $0.05 \mathrm{~N}$ TBAH solution in isopropyl alcohol, graphs as $\mathrm{mV}-\mathrm{mL}$ (TBAH) are given in Fig. 3.
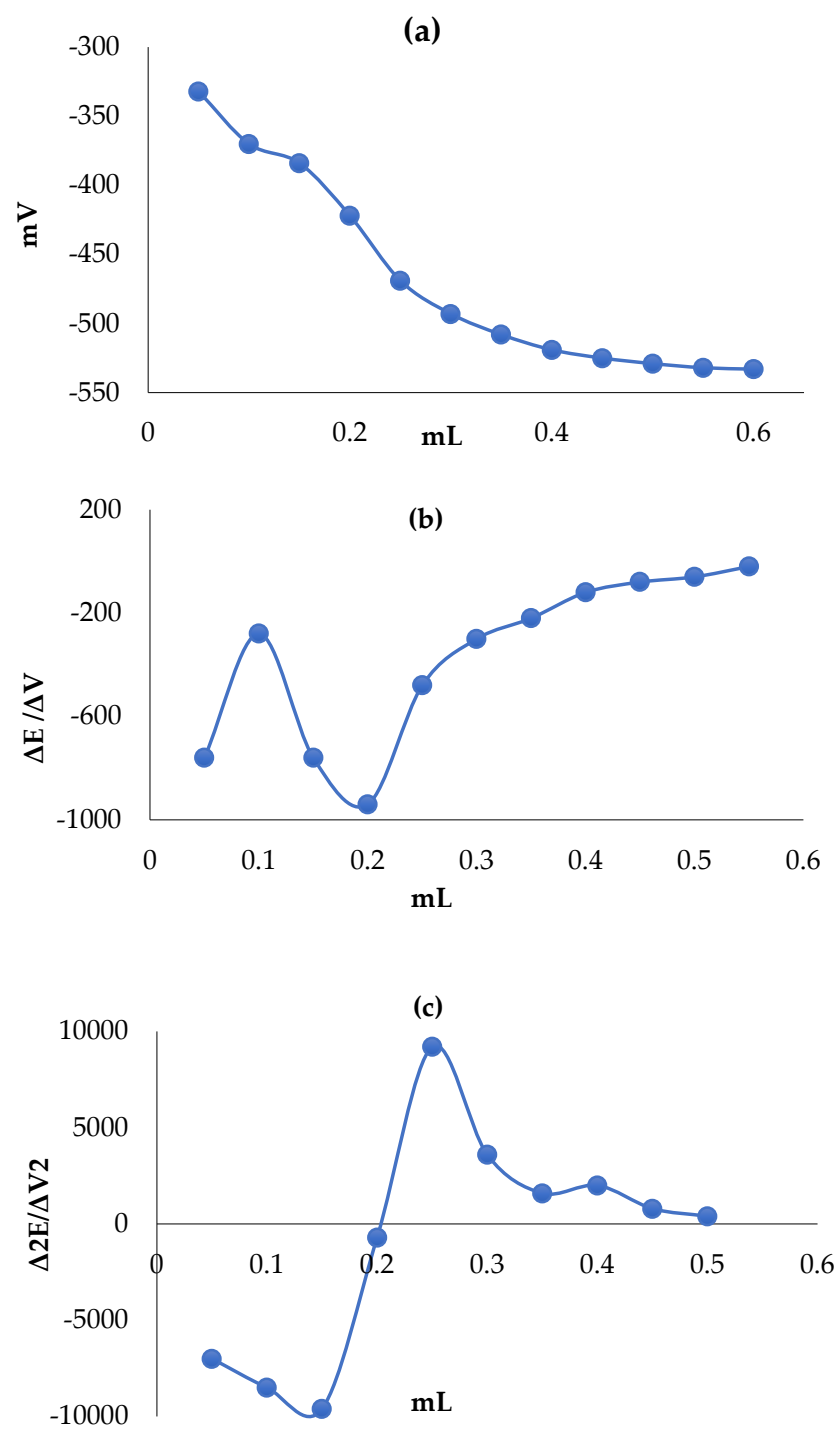

Figure 2. Compound 1 b: $\quad$ a. $m L-m V$ curve $\quad$ b. $\Delta \mathrm{E} / \Delta \mathrm{V}$ curve c. $\Delta^{2} \mathrm{E} / \Delta \mathrm{V}^{2}$ curve

Table 1. Acidity strengths of 3-alkyl(aryl)-4-(3-hydroxy-4methoxybenzylidenamino)-4,5-dihydro-1 $\mathrm{H}-1,2,4$-triazol-5-ones in amphiprotic and dipolar aprotic solvents

\begin{tabular}{|c|c|c|c|c|c|c|c|c|}
\hline \multirow[t]{2}{*}{ Compound } & \multicolumn{2}{|c|}{$\begin{array}{c}\text { Isopropyl } \\
\text { alcohol }\end{array}$} & \multicolumn{2}{|c|}{$\begin{array}{c}\text { tert-butyl } \\
\text { alcohol }\end{array}$} & \multicolumn{2}{|c|}{ Acetone } & \multicolumn{2}{|c|}{ DMF } \\
\hline & $\mathrm{p} K_{\mathrm{a}}$ & Hnp & $\mathrm{p} K_{\mathrm{a}}$ & Hnp & $\mathrm{p} K_{\mathrm{a}}$ & Hnp & $\mathrm{p} K \mathrm{a}$ & Hnp \\
\hline 1a & 15,09 & -388 & - & - & 12,72 & -274 & 15,20 & -337 \\
\hline $1 b$ & 10,23 & -168 & - & -568 & 12,72 & -248 & 15,60 & -370 \\
\hline 1c & 14,73 & -346 & 12,77 & -290 & - & - & 15,24 & -341 \\
\hline $1 d$ & 14,43 & -317 & - & - & 16,49 & -381 & 14,47 & -307 \\
\hline 1e & 14,55 & -391 & - & - & 15,38 & -361 & 17,20 & -415 \\
\hline 1f & 15,58 & -351 & 14,20 & -290 & 12,49 & -225 & 14,12 & -297 \\
\hline $1 \mathrm{~g}$ & 16,02 & -370 & 13,05 & -295 & 15,40 & -364 & 14,56 & -313 \\
\hline $1 \mathrm{~h}$ & 11,56 & -226 & - & - & 15,85 & -372 & 15,51 & -355 \\
\hline $1 \mathrm{i}$ & 13,63 & -271 & - & - & 16,75 & -363 & 18,24 & -460 \\
\hline $\mathbf{1 j}$ & 14,98 & -331 & 14,23 & -357 & 12,90 & -249 & 16,50 & -390 \\
\hline
\end{tabular}

Half-neutralization potentials were calculated from the graphs obtained and plotted in the excel program. Calculated Hnp and $\mathrm{pK}$ a values are given in Table 1.

3-Alkyl(Aryl)-4-(3-hydroxy-4-methoxybenzylidenamino)-4,5-dihydro-1H-1,2,4-triazol-5-ones determined by potentiometric titration in amphiprotic and dipolar aprotic solvents. Acidity strength (Fig. 4), functional groups, autoprotolysis constant, dielectric constant, and the leveling-differentiation effect was investigated.

Classification of acidity strength in different solvents can be made by the dielectric constant. It was stated that the theoretical increase in $\mathrm{p} K_{\mathrm{a}}$ values in four solvents should be tert-butyl alcohol < isopropyl alcohol < acetone $<$ DMF. Experimental results suitable for the theoretical sequence were obtained for compounds $\mathbf{1 a}, \mathbf{1 b}, \mathbf{1 d}, \mathbf{1 e}$, $\mathbf{1 h}$, and $\mathbf{1 i}$ in amphiprotic solvents. Since typical Sshaped curves for other compounds could not be obtained, acidity constants could not be determined in the tert-butanol solvent.

Theoretically, it has been stated that the $\mathrm{p} K \mathrm{a}$ values of the compounds in the DMF medium from dipolar aprotic solvents are higher than that of acetone. The experimental results showed a result contrary to the theoretical order of compounds $\mathbf{1 d}, \mathbf{1 g}$, and $\mathbf{1 h}$. Typical S-shaped curves could not be obtained for compound 1 in acetone medium, so they could not be compared. For other compounds, theoretical order and experimental results were in agreement. This situation, which is similar to other studies, can be explained as follows.

Solvents such as acetone and N, Ndimethylformamide form lyonium ions but not lyate ions. HX is acid (molecular), $\mathrm{S}$ is a solvent and DMF (protophilic solvent) formed the following equilibrium.

$$
H X+S \underset{1}{\leftrightarrow} S \cdots \cdots+\underset{2}{\leftrightarrow} S H^{+} X^{-} \underset{3}{\leftrightarrow} S H^{+}+X^{-}
$$

When protophilic solvents are used for the equilibrium given in Equation 1, the equilibrium number (1) and (2) mostly shifts to the direction in which it is written, while the equilibrium number (3) shifts slightly to the right. In equilibrium number (3), the strongest acid in the free environment is $\mathrm{SH}^{+}$. This strain reacts directly with the titrant. However, in the case of protophobic solvent such as acetone, the equilibrium shifts slightly to the right in Equation 2. Equilibrium (3) shifts slightly to the right. In this case, $\mathrm{SH}^{+}$in protophobic solvent is a much stronger acid.

Considering the autoprotolysis constant, it was seen that the Hnp values of the compounds and the potential ranges of the solvents in tert-butyl alcohol, isopropyl alcohol, DMF, and acetone medium are weakly acidic when compared with the data in Table 2. 

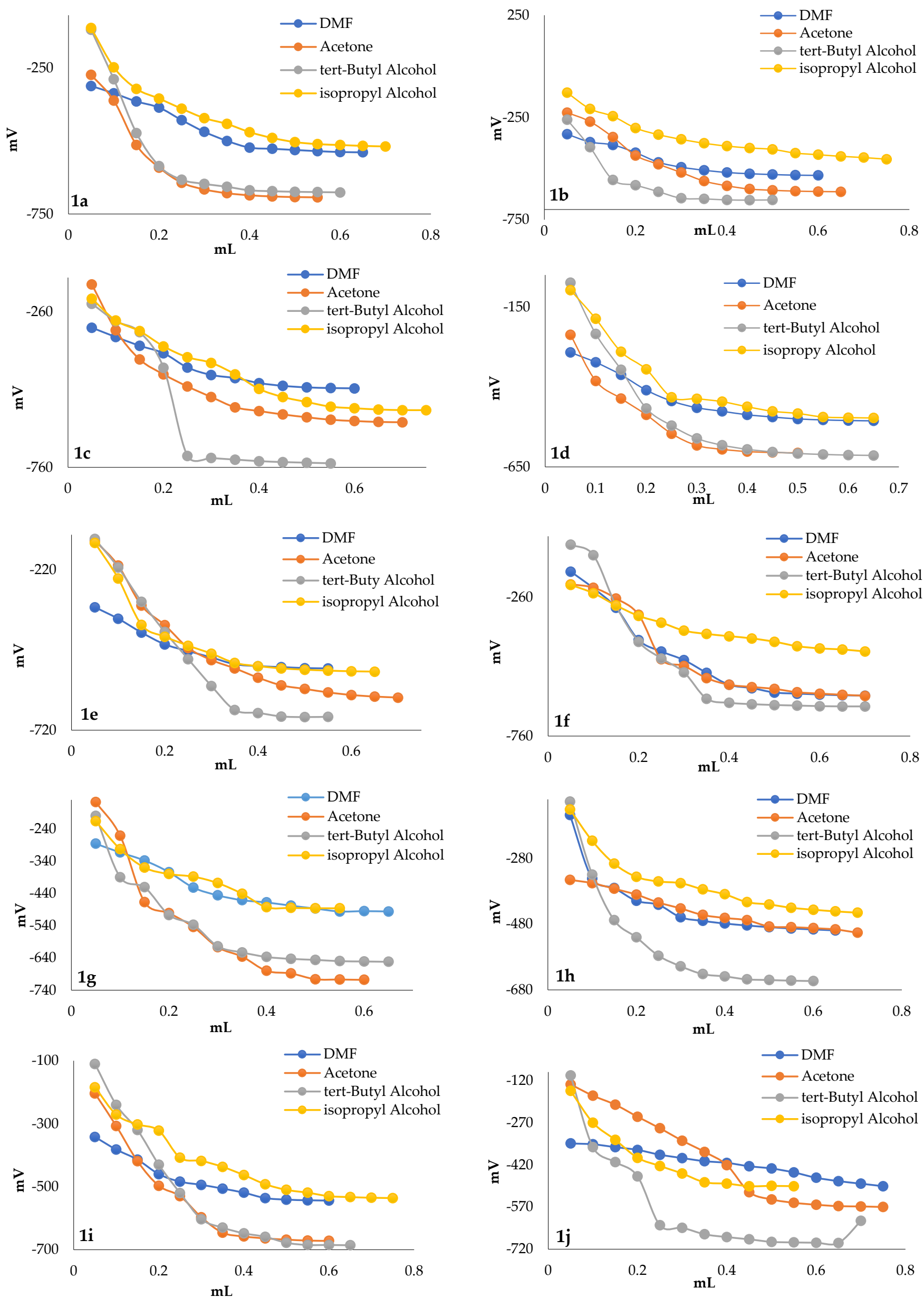

Figure 3. Potentiometric titration graphs of compounds 1a-j with TBAH in isopropyl alcohol 


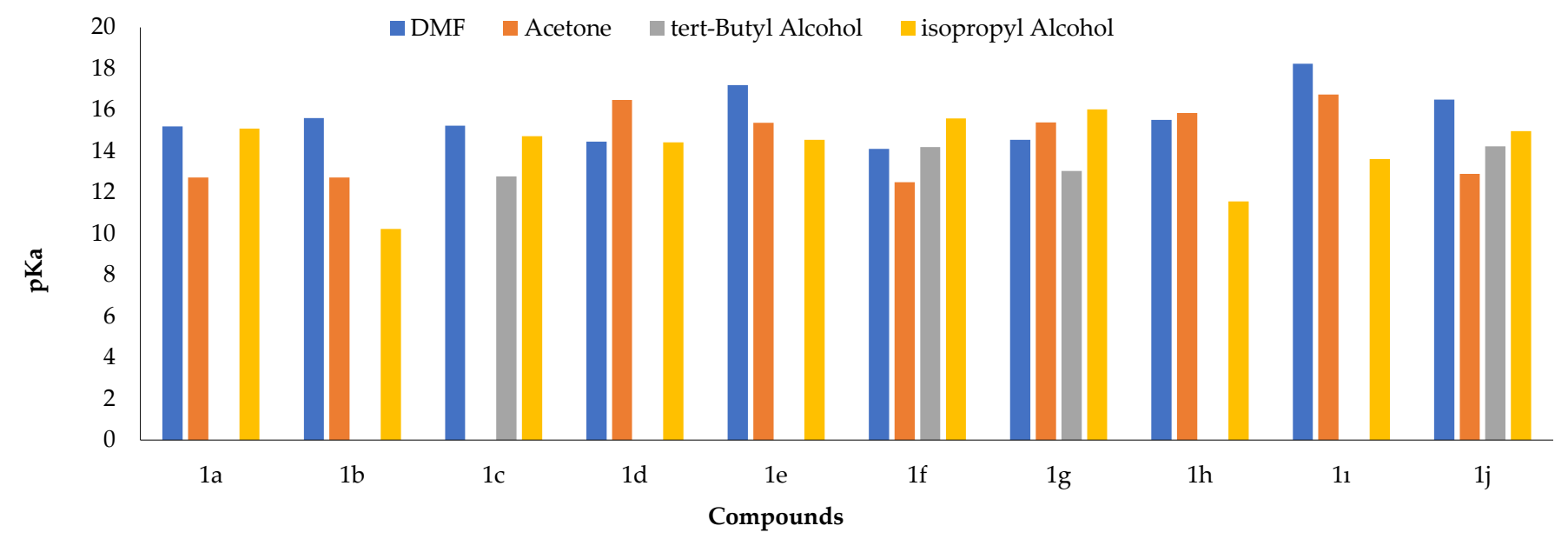

Figure 4. $\mathrm{pK}$ a-compounds plot for compound 1

Table 2. Potential ranges of solvents and measured Hnp values of 3alkyl(aryl)-4-(3-hydroxy-4-methoxybenzylidenamino)-4,5-dihydro1H-1,2,4-triazol-5-ones

\begin{tabular}{|c|c|c|c|c|c|c|c|}
\hline \multirow{2}{*}{ Solvents } & \multicolumn{2}{|c|}{$\begin{array}{c}\text { Potential } \\
\text { Range }\end{array}$} & \multicolumn{2}{|c|}{$\begin{array}{c}\text { Potential } \\
\text { Range }\end{array}$} & \multicolumn{3}{|c|}{ Potential Measured Compounds } \\
\hline & $(\mathrm{m}$ & & $(\mathrm{m}$ & & $(\mathrm{mV})^{\mathrm{b}}$ & $\mathrm{Hn}_{\mathrm{F}}$ & \\
\hline $\begin{array}{l}\text { tert-butyl } \\
\text { alcohol }\end{array}$ & - & - & - & - & 1200 & -290 & -568 \\
\hline $\begin{array}{l}\text { Isopropyl } \\
\text { alcohol }\end{array}$ & -750 & +400 & -720 & +407 & 1000 & -168 & -391 \\
\hline Acetone & -970 & +660 & -965 & +598 & 1550 & -225 & -381 \\
\hline DMF & -1000 & +270 & -900 & +237 & 1300 & -297 & -460 \\
\hline
\end{tabular}

\section{Conclusion}

Research results; 3-alkyl(aryl)-4-(3-hydroxy-4methoxybenzylidenamino)-4,5-dihydro-1H-1,2,4-

triazol-5-ones have proven to be weakly acidic in anhydrous media solvents. When the acidity strength is listed according to the dielectric constant and acidity constant, it has been determined that $1 \mathrm{~d}, 1 \mathrm{~g}$, and $1 \mathrm{~h}$ in $\mathrm{DMF}$ and acetone environments are not suitable for the theoretical order [24,25], but suitable for other environments. Compounds $\mathbf{1 a}$ and $\mathbf{1 b}$ were leveled in acetone medium. It has been differentiated in other solvents. However, the molecular effect was examined and it was concluded that there was no significant difference due to the distance of the functional groups to the acidic proton and the solvent effect.

\section{Acknowledgments}

This study was supported by a grant (Project Number: 2008.116.006.1) from the Scientific Research Projects Coordination Unit of Karadeniz Technical University.

\section{References}

[1] D.A. Skoog, D.M. West, F.J. Holler, S.R. Crouch, Analitik Kimya Temel İlkeler, Translators: E. Kılıç, H. Yılmaz, 2007, Turkey, Bilim Yayıncilık.
[2] J. Reijenga, A. Hoof, A. Loon, B. Teunissen, Development of methods for the determination of $\mathrm{pK}$ a values, Anal Chem Insights, 8, 2013, 53-71.

[3] S. Zafar, S. Akhtar, T. Tariq, N. Mushtag, A. Akram, A. Ahmed, M. Arif, S. Naeem, S. Anwar, Determination of pKa values of new phenacyl-piperidine derivatives by potentiometric titration method in aqueous medium at room temperature $\left(25 \pm 0.5{ }^{\circ} \mathrm{C}\right)$, Pak J Pharm Sci, 27(4), 2014, 925-929.

[4] S. Sharif Manesh, M. Masrournia, Carbon nitride nanoparticles modifed carbon paste electrodes as potentiometric sensors for determination of nickel(II) and chromium(III) ions in tap water samples, J Iran Chem Soc, 18, 2021,1219-1229.

[5] Ö. Işıldak, O. Özbek, Application of potentiometric sensors in real samples, Crit Rev Anal Chem, 2020, doi:10.1080/10408347.2019.1711013.

[6] K. Braininaa, N. Stozhko, M. Bukharinova, E, Khamzina, M. Vidrevich, Potentiometric method of plant microsuspensions antioxidant activity determination, Food Chem, 278, 2019, 653658.

[7] Kh.Z. Brainina, E.L. Gerasimova, D.P. Varzakova, S.L. Balezin, I.G. Portnov, V.A. Makutina, E.V. Tyrchaninov, Potentiometric method for evaluating the oxidant/ antioxidant activity of seminal and follicular fluids and clinical significance of this parameter for human reproductive function, Open Chem Biomed Methods J, 5, 2012, 1-7.

[8] Kh.Z. Brainina, A.V. Ivanova, E.N. Sharafutdinova, E.L. Lozovskaya, E.I. Shkarina, Potentiometry as a method of antioxidant activity investigation, Talanta, 71, 2007, 13-18.

[9] K.D. Bhesaniya, S. Baluja, Potentiometric determination of dissociation constant and thermodynamic parameters of dissociation process of some newly synthesized pyrimidine derivatives in $\mathrm{MeOH} / \mathrm{DMF}$-water medium at different temperatures, J Mol Liq, 190, 2014, 190-195.

[10] Z. Farkas, M. Posa, V. Tepavcevic, Determination of $\mathrm{pK}$ a values of oxocholanoic acids by potentiometric titration, J Surfactants Deterg, 17, 2014, 609-614.

[11] V.R. Almeida, B. Szpoganicza, S. Bonnevilleb, Potentiometric titration and out-of-equilibrium $\mathrm{pH}$ response of the biotite-water system, J Brazil Chem Soc, 26(9), 2015, 1848-1860.

[12] A.S. Katea, K.C. Basavaraju, A simple potentiometric titration method for estimation of maleic anhydride in high molecular weight styrene-maleic anhydride copolymer, Polym Test, 65, 2018, 369-373.

[13] M. Lakubowska, B. Bas, E. Niewiara, W. Reczynski, W.W. Kubiak, Potentiometric titration of industrial samples-end-point detection by means of wavelets, AIP Conference Proceedings, 1148, 2009, 613-616.

[14] T. Lisa, D. Chansyanah, S. Marina, K. Nina, S. Andrian, Using potentiometric acid-base titration to determine $\mathrm{pK}$ a from 
Mangosteen Pericarps Extract, Periód Tchê Quím, 16, 2019, 768773.

[15] N. Demirbaş, R. Uğurluoğlu, A. Demirbaş, Synthesis of 3Alkyl(Aryl)-4-Alkylidenamino-4,5-dihydro-1H-1,2,4-Triazol-5Ones as Antitumor Agents, Bioorgan Med Chem, 10, 2002, 37173723.

[16] Ş. Bahçeci, N. Yıldırım, Ö. Gürsoy-Kol, S. Manap, M. Beytur, H. Yuksek, Synthesis, characterization and antioxidant properties of new 3-alkyl(aryl)-4-(3-hydroxy-4-methoxy-benzylidenamino)4,5-dihydro-1H-1,2,4-triazol-5-ones, Rasayan J Chem, 9, 2016, 494501.

[17] E. Kılıc, O. Atakol, E. Canel, Z. Alibeşeoğlu, T. Gunduz, F. Köseoğlu, Potentiometric investigation of the effects of several substituents on the basicity of benzilidene-o-hydroxyaniline, Turk J Chem, 22, 1998, 387-391.

[18] H. Yüksek, E. Koca, Ö. Gürsoy-Kol, O, Akyıldırım, M. Çelebier, Synthesis, in vitro antioxidant activity, and physicochemical properties of novel 4,5-dihydro-1H-1,2,4-triazol-5-one derivatives, J Mol Liq, 206, 2015, 359-366.

[19] M. Kurtoğlu, N. Birbiçer, Ü. Kimyonsen, S. Serin, Determination of $\mathrm{pK}$ a values of some azo dyes in acetonitrile with perchloric acid, Dyes Pigments, 41, 1999, 143-147.

[20] N. Gündüz, T. Gündüz, M. Havyalı, Titrations in non-aqueous media: Potentiometric investigation of symmetrical and unsymetrical tetra-aryl porphyrins with 4- nitrophenyl and 4aminophenyl substituents in nitrobenzene solvent, Talanta, 48, 1999, 71-79.

[21] Z. Ocak, Amfiprotik ve dipolar aprotik çözücülerde 3-(4-Aril) propiyonik asit türevlerinin asitlik kuvvetleri, Iğdır Üniversitesi Fen Bilimleri Enstitüsü Dergisi, 10(3), 2020, 1876-1885.

[22] O. Hakli, K. Ertekin, M.S. Ozer, S. Aycan, Determination of $\mathrm{pK}$ values of clinically important perfluorochemicals in nonaqueous media, J Anal Chem, 63(11), 2008, 1051-1056.

[23] R.H. Loeppert, L.W. Zelazny, B.G. Volk, Titration of pHdependent sites of kaolinite in water and selected nonaqueous solvents, Clay Clay Miner, 27 (1), 1979, 57-62.

[24] H. Yüksek, M. Küçük, M. Alkan, Ş. Bahçeci, S. Kolaylı, Z. Ocak, U. Ocak, E. Şahinbaş, M. Ocak, Synthesis and antioxidant activities of some new 4-(4-hydroxy-benzylidenamino)-4,5dihydro-1H-1,2,4-triazol-5-one derivatives with their acidic properties, Asian J Chem, 18(1), 2006, 539-550.

[25] A. Arslantaş, H. Yüksek, Ö. Gürsoy Kol, Z. Ocak, Z. Tomruk, M. Calapoğlu, Study of antioxidant properties and DNA interaction of some novel 4,5-dihydro-1H-1,2,4-triazol-5-one derivates, Asian J Chem, 24(8), 2012, 3327-3334. 